\title{
Improving the Competence of Teachers in Maritime Vocational Schools in Indonesia
}

\author{
Kurniawan Abadi*, Sutipto, Ivan Hanafi \\ Educational Management Department \\ University State of Jakarta \\ Jakarta, Indonesia \\ *kurniawan37@kap3b.net
}

\begin{abstract}
This study aims to analyze the effect of coaching, supervision, and work motivation on the competence of Sailing Vocational Teachers in Indonesia. In addition to knowing whether there is a good relationship between each variable directly. This research uses a quantitative method with a path analysis approach. The population of this study is the Vocational School teachers in Indonesia who have TOT Model Course 6.09 certificates totaling 362 teachers with a sample of 190 teachers. The results showed the path coefficient of several variables related to teacher competence, including coaching, supervision, and work motivation. The novelty in this study found that the competence of overseas shipping teachers is dominated by the training received in large numbers of 0.418 with the largest indicator which means an increase in knowledge, this is due to being a teacher. Set by IMO (International Maritime Organization).
\end{abstract}

Keywords-competency, controlling, training, work motivation

\section{INTRODUCTION}

Someone said to be a professional must have several requirements, including competence following their job [1]. Competence is a complex combination of knowledge, skills, understanding, values, attitudes, and desires that lead to effective humanitarian action and are manifested in a specific domain [2]. Teachers who are a person's profession in sharing information are required to work professionally, especially in the use of digital media today [3]. Current technological developments cannot be stopped anymore, in the learning process, students and teachers are required to be able to apply them [4,5]. Every citizen has the right to education [6] worthy. Vocational High School (SMK) is one of the stages of the education system in Indonesia, in the learning process Vocational High Schools (SMK) is unique, namely, $60 \%$ of the learning process is practice, and $40 \%$ is a theory, Vocational High Schools (SMK) are demanded to produce output in the form of students who can work professionally according to their expertise [7]. In realizing this expectation, teachers as the smallest unit of a school are required to increase their role in the learning process in the classroom by designing, developing, and continuously updating all information related to learning received following the demands of the market share [8].
Teachers as professional educators have the main task of educating, teaching, guiding, directing, training, assessing, and evaluating students in early childhood education through formal education, basic education, and secondary education. Apart from the main task, the teacher is also possible to have other tasks that are relevant to school functions [9]. The teacher performance appraisal uses the same competencies and performance indicators for the 4 functional teacher positions (first teacher, young teacher, middle teacher, and the main teacher). Teacher performance appraisal includes assessing the activities of planning and implementing learning, evaluating and assessing, analyzing the results of the assessment, and implementing follow-up on the results of the assessment, based on the Regulation of the Minister of National Education No. 16 of 2007 concerning Academic Qualification Standards and teacher competencies, there are 4 competencies that teachers must have, namely my pedagogical, personal, social and professional competencies which are translated into 24 subcompetencies. Meanwhile, in the teacher performance appraisal system, only 14 sub-competencies were assessed as formulated by the National Education Standards Agency (BSNP) with 78 indicators.

Based on the description above, the teacher's performance is measured through 4 competencies where each competency has a measuring instrument, this is in line with the results of Toran's research which said that the competencies possessed by a teacher will be reflected in the performance value given by the leader to him [10]. This proves that the competence of teachers is very important and has a big impact both on their performance and on the quality of their students' graduates [11].

Through education, one way to improve the quality of Indonesian citizens. Education is closely related to the quality of teachers, this is supported by the results of research conducted by Hattie which states that teacher competence is an important factor in determining the quality of education [12], $30 \%$ of the quality of the school is determined by the competence of the teacher [13]. To continuously improve teacher competence, there are several training programs implemented by the government through teaching programs 
that are prepared to face future challenges that are closely related to the development of information technology [14].

Also, training has a significant role in increasing competence, this is in line with Barnes' research results which state that school quality is determined by the quality of its teachers and to improve their competence the best thing is to provide training to teachers according to their educational background and work unit each [15]. Within the scope of Shipping Middle Schools in Indonesia, the authorized and officially licensed institutions in providing standardized training from IMO are through the Ministry of Transportation which is delegated to BPSDM of the Ministry of Transportation.

The training received by teachers has an important role in increasing motivation at work and motivating teachers to improve their competence. This is in line with Copper and Kaye's research which proved that training has a significant effect on the formation of employee competencies [16,17]. The training itself is a short-term educational process that uses a systematic and organized procedure carried out by an institution, not all institutions are allowed to establish a training activity, these institutions are generally government-owned which has a vision and mission to improve the quality of employees students.

The recruitment of these professionals is to overcome the problem of a shortage of productive teachers as many as 91,861 teachers, with details of 41,861 in State Vocational High Schools and 50,000 at private Vocational High Schools. With the issuance of Presidential Instruction of the Republic of Indonesia Number 9 of 2016 concerning the Revitalization of Vocational High Schools in the Context of Improving the Quality and Competitiveness of Indonesian Human Resources with the task of the Minister of Transportation to improve guidance for vocational schools whose vocational is related to transportation. So the Ministry of Transportation must conduct training, especially on the competence of vocational teachers, especially in the maritime field.

Shipping education institutions consisting of SMK and academies run by the community (private) can be said to be unique because the school or institutional governance is regulated by the Ministry of Education and Culture, but for the competency standards of graduates, they must follow the criteria of the Ministry of Transportation. Professionals with a wealth of experience will be given training and take a standardized competency exam after which they are given a teaching certificate. Multitasking work and very complex. The main individual differences between groups of students who attend the same class demand adaptive teaching. Teachers are challenged to meet diverse learning needs and to adapt their teaching to heterogeneous academic abilities and multiple interests and motivations [18]. Teachers are challenged to meet diverse learning needs and adapt their teaching to heterogeneous academic abilities and various interests and motivations [19].
Based on the supervision of the principal, there is a finding that many teachers in the learning planning making process have not yet referred to the International Maritime Organization Model Course which is required by the Ministry of Transportation. This is very unfortunate because in addition to reducing the quality of graduates and detrimental to students. This problem can be addressed by providing appropriate and appropriate training, this is similarly expressed by Bengo saying that training can improve the competence of teachers [20].

The training that can be provided such as cognitive training, instructional training depends on the ability of the trainer to know the teacher's perspective and listen carefully to conversational training which has an impact on teacher competence. The same thing was expressed by Cynthia D. Fisher that competence can be influenced by many things, one of which is work motivation, with high work motivation can have an impact on one's competence at work [21]. Motivation is encouragement from within or without the teacher to work optimally following the main task and function.

On the other hand, teachers are expected to build cooperative relationships with relevant trainers such as BPSDM of the Ministry of Transportation who are in charge of them, this will affect the quality of teachers in teaching their students. Also, a systematic and continuous training process can help teachers maintain their competence [22]. Jennifer Jacobs in her research explained that the training provided to teachers had an impact on an increase of 50\% towards increasing teacher competence [23]. Teacher training is an activity that must be carried out continuously and continuously because teacher training leads to increased performance which is a function of the individual characteristics of the teacher, which includes attitudes, desires, abilities, and motivation. Teacher training begins with conducting an evaluation of the implementation of the teaching and learning process, finding weaknesses or problems faced by the teacher.

Based on the descriptions and data found in the field, the competence of teachers vocational high School has a very strategic role, besides that many factors can affect teacher competence in carrying out their obligations, this is what makes researchers interested in studying more deeply to find solutions to productive teacher competency problems. Who has a TOT certificate for the Couse Model 6.09 in Indonesia.

\section{RESEARCH METHODS}

This research uses quantitative with a path analysis method. In the process of collecting data via google form be collected by respondents. The population is educators especially those who teach in general support education commands with a total of 169 teacher.

\section{RESULTS AND DISCUSSION}

The results of the first hypothesis analysis resulted in the finding that training had a positive direct effect on competence. Based on these findings, it can be concluded that competence is 
directly influenced positively by training. Increased training will result in increased competence. The results of this study are in line with the opinion of Barnes et al. explaining that the training received by employees can increase competence, the knowledge received by teachers through the training they undergo can affect the competence of teachers in work [15]. The quality of a school is determined by the quality of its teachers or Great School $=$ Great Teacher. To promote education in Indonesia, it is no less important to improve the competence and quality of teachers, one of which is by providing training to teachers according to the needs of each teacher. The training provided to teachers can help in increasing the skills and knowledge of teachers. Also, it can increase the achievement of the students it teaches. Sometimes there are boundaries drawn between training and development, with the development that is broader in scope and focuses on the individual to achieve new abilities that are useful for both his current and future work.

To meet all these standards, Pelayaran SMK teachers need training according to their needs, this is in line with the following research conducted by Kaye et.al. This study proves that the training provided has an important role in motivating employees to increase their competence and self-confidence at work. There are several efforts that organizations or institutions carry out by providing training according to the needs of employees and working with related agencies [17].

The training conducted by the Ministry of Transportation's BPSDM has several objectives including; increasing skills and increasing knowledge for vocational school teachers. With the training provided, teachers are expected to increase their competence at work [24]. The training received by teachers, it can help teachers get updated information according to their needs in teaching and can improve teacher competence at work. Further research by Naweed and Ambrosetti, shows that participants who take part in the training are proven to be able to improve their ability to work and improve their competence. [25]. The success of the learning process is greatly influenced by various factors. The human resource factor is very related. The principal as the learning leader seeks to guide the development and improvement of the learning process. One form of activity that can be carried out is in the form of Classroom Action Research Report Preparation Training.

The results of the second hypothesis analysis resulted in the finding that work motivation has a positive direct effect on competence. Based on these findings, it can be concluded that competence is directly influenced positively by work motivation. Increased work motivation will result in increased competence.

Based on the researchers' observations, these two factors support each other in improving the quality of teacher work. Teachers who have high work motivation will tend to work hard and try to work as well as possible. Teachers who participate in various education and training activities to improve self-quality are proof that teachers who participate in various self-development activities will certainly be different from teachers who have never participated in any training activities and will indirectly affect their competence.

The core activity of the educational process is teaching and learning activities. In carrying out teaching assignments, teachers need to have professional competence because teachers are dealing directly with students so they must know exactly what to convey. The achievement of learning objectives is an assumption that the teacher can master the subject matter. Therefore, if the learning objectives can be achieved properly, the teacher's performance can also be said to be good. To find out whether the teacher is doing his job well or not, that is by looking at the physical evidence of the teaching and learning process administration where the document is used to assess the teacher's assignment from planning to learn to follow-up. However, overall the teacher's performance can be said to be good, namely, it is proven that the teacher prepares a teaching program plan according to the standards, compiles learning reflections contained in the daily lesson plan book, task analysis sheets, and daily tests, lesson progress reports, semester reports. Motivation or encouragement to work is very important for the high and low productivity of an organization. Without the motivation of the teachers to work together for the benefit of the school, certainly, the goals that have been set will not be achieved.

Humphreys explains that work motivation is a development of motivation theory: Traditional motivation theory is incomplete and they propose that a comprehensive model of work motivation should include the elements of individual personality and aspects of the effort, individual abilities, expectations, instrumentality, valence, behavior directed at goals, intrinsic and extrinsic rewards, job satisfaction, leadership and perceptions of fairness; they believe that people with different personalities have different needs and wants and exhibit various preferences in order of needs as well [26]

\section{CONCLUSION}

Training has a positive direct effect on competence. This means that the quality of teachers is a reflection of the quality of the school and its graduates. To maintain the quality of schools, the most important thing is to maintain teacher competence through training programs provided to teachers. Supervision has a positive direct effect on competence. This means that the role of the principal in determining teacher performance standards in working according to the IMO (International Maritime Organization) can improve teacher competence. Work motivation has a positive direct effect on competence. This means that teacher motivation has an important role in determining his / her competence at work, by participating in several trainings and workshops following their field of expertise.

\section{ACKNOWLEDGMENT}

This article is part of a dissertation based on the results of the study. Thank you to superiors, Sutjipto, and Ivan Hanafi. The author also thanks to the shipping vocational high school 
teacher, to educators who have taken the time to provide information that is important for this research. Hopefully, this article is useful and input for improving the quality of education thanks to the shipping vocational high school.

\section{REFERENCES}

[1] S. Lester, "Reconciling activity-based descriptions of competence with professional work," Higher Education, Skills and Work-Based Learning, vol. 7, no. 4, pp. 381-393, 2017.

[2] R. Deakin Crick, Learning power in practice: a guide for teachers. London; Thousand Oaks, Calif: Paul Chapman, 2006.

[3] S. Prestridge and J. Tondeur, "Exploring Elements That Support Teachers Engagement in Online Professional Development," Education Sciences, vol. 5, no. 3, pp. 199-219, 2015.

[4] K. Burden, P. Aubusson, S. Brindley, and S. Schuck, "Changing knowledge, changing technology: implications for teacher education futures," Journal of Education for Teaching, vol. 42, no. 1, pp. 4-16, Jan. 2016.

[5] G.B. Gudmundsdottir and O.E. Hatlevik, "Newly qualified teachers' professional digital competence: implications for teacher education," European Journal of Teacher Education, vol. 41, no. 2, pp. 214-231, 2018.

[6] UUD 1945, Undang-Undang Dasar Negara Republik Indonesia. 1945, p 12

[7] E. Gokce, "The Development of a Scale to Determine General Competency for Primary School Teachers in Turkey: A Validity and Reliability Study," The Anthropologist, vol. 20, no. 1-2, pp. 360-368, Apr. 2015.

[8] R.I. Aðalsteinsson, I.B. Frímannsdóttir, and S. Konráðsson, "Teachers' self-esteem and self-efficacy," Scandinavian Journal of Educational Research, vol. 58, no. 5, pp. 540-550, Sep. 2014.

[9] S. Gultom, Pedoman Pelaksanaan Penilaian Kinerja Guru. Kementrian Pendidikan dan Kebudayaan, 2012.

[10] M. Toran, "Does sense of efficacy predict classroom management skills? An analysis of the pre-school teacher's professional competency," Early Child Development and Care, pp. 1-13, Sep. 2017.

[11] A. Walsh, S. Koppula, V. Antao, C. Bethune, S. Cameron, T. Cavett and M. Dove, "Preparing teachers for competency-based medical education: Fundamental teaching activities," Medical teacher, vol. 40, no. 1, pp. 8085,2018 .
[12] J. Hattie, "Kualitas Pendidikan di sekolah.” 2018.

[13] M. Cochran-Smith, "Studying teacher education what we know and need to know," Journal of Teacher Education, vol. 56, no. 4, pp. 301-306, 2005.

[14] M. Barber, M. Mourshed, and Company, M. Barber, and M. Mourshed "How the World's Best-Performing School Systems Come Out On Top," p. 56, 2007.

[15] A.E. Barnes, S.S. Zuilkowski, D. Mekonnen, and F. Ramos-Mattoussi, "Improving teacher training in Ethiopia: Shifting the content and approach of pre-service teacher education," Teaching and Teacher Education, vol. 70, pp. 1-11, Feb. 2018

[16] D. Cooper and J.B. Allen, "The coaching process of the expert coach: a coach led approach," Sports Coaching Review, vol. 0629, no. August, pp. 1-29, 2017

[17] D. Kaye, A. Mwanika, and N. Sewankambo, "Influence of the training experience of Makerere University medical and nursing graduates on willingness and competence to work in rural health facilities," p. 10 2010 .

[18] G. Brante, "Multitasking and synchronous work: Complexities in teacher work," Teaching and Teacher Education, vol. 25, no. 3, pp. 430 436, Apr. 2009.

[19] F. Vogt and M. Rogalla, "Developing Adaptive Teaching Competency through coaching," Teaching and Teacher Education, vol. 25, no. 8, pp. 1051-1060, 2009.

[20] P. Bengo, "Secondary mathematics coaching: The components of effective mathematics coaching and implications," Teaching and Teacher Education, vol. 60, pp. 88-96, 2016.

[21] C.D. Fisher, "The effects of personal control, competence, and extrinsic reward systems on intrinsic motivation," Organizational Behavior and Human Performance, vol. 21, no. 3, pp. 273-288, 1978.

[22] A. Atteberry and A.S. Bryk, "Analyzing Teacher Participation in Literacy Coaching Activities," The Elementary School Journal, vol. 112 no. 2, pp. 356-382, Dec. 2011.

[23] J. Jacobs, A. Boardman, A. Potvin, and C. Wang, "Understanding teacher resistance to instructional coaching," Professional Development in Education, vol. 5257, no. November, pp. 1-14, 2017.

[24] G. Dessler, Human Resource Management, 15th ed. United State of America: Pearson, 2017.

[25] A. Naweed, Abrosetti, and Angelina, "Mentoring in the Rail contex: The influence of training, style and practice," Journal of Workplace Learning, vol. 27, no. 1, pp. 3-18, 2015.

[26] D. Ulrich, "Coaching for results," Business Strategy Series, vol. 9, no. 3, pp. 104-114, 2008. 